\title{
The scientist as historian: Paulo Vanzolini and the origins of zoology in Brazil
}

\section{O cientista como historiador: Paulo Vanzolini e as origens da zoologia no Brasil}

Francisco Inácio Bastos

Pesquisador titular do Instituto de Comunicação e Informação Científica e Tecnológica em Saúde/Fiocruz; professor da Escola Nacional de Saúde Pública Sérgio Arouca/Fiocruz. Av. Brasil, 4365/Biblioteca de Manguinhos, suíte 229 21045-900 - Rio de Janeiro - RJ - Brasil

francisco.inacio.bastos@hotmail.com

\section{Magali Romero Sá}

Professora e pesquisadora do Programa de Pós-graduação em História das Ciências e da Saúde/ Casa de Oswaldo Cruz/Fundação Oswaldo Cruz. Av. Brasil, 4036/405

21040-361 - Rio de Janeiro - RJ - Brasil

magali@coc.fiocruz.br

Recebido para publicação em agosto de 2010.

Aprovado para publicação em janeiro de 2011.
BASTOS, Francisco Inácio; SÁ, Magali Romero. The scientist as historian: Paulo Vanzolini and the origins of zoology in Brazil. História, Ciências, Saúde - Manguinhos, Rio de Janeiro, v.18, n.4, out.-dez. 2011, p.1021-1038.

\section{Abstract}

The Brazilian Paulo Vanzolini is one of the leading herpetologists worldwide. Besides his publications as a zoologist and his activities as a former museum curator and policymaker, Vanzolini pursued a long-life career as a musician and contributed to many different fields such as biostatistics, biogeography and the history of science. The paper analyzes his historical contributions to a key chapter of science in Southern America, the legacy of the so-called traveler naturalists. His analyses comprise major scientists such as Marcgrave, Spix, von Martius, WiedNeuwied, Castelnau, and Agassiz, are informed by re-analyses of original sources and represent an invaluable repository of historical and scientific information.

Keywords: history of biology; colonial history; zoology; traveler naturalists; Brazil.

\section{Resumo}

O brasileiro Paulo Vanzolini é um dos mais importantes herpetologistas do mundo. Além de suas publicações como zoólogo, das atividades de curadoria museológica e de sua atuação na formulação de políticas científicas, Vanzolini tem longa carreira como músico e contribuições a diferentes áreas de conhecimento como bioestatística, biogeografia e história das ciências. O artigo analisa suas contribuições a capítulo fundamental da história das ciências na América do Sul, o legado dos naturalistas viajantes. Suas análises incluem importantes cientistas como Marcgrave, Spix, von Martius, Wied-Neuwied, Castelnau e Agassiz, são feitas a partir da retomada de fontes originais e representam valioso repositório de informações históricas ecientíficas.

Palavras-chave: história da biologia; história colonial; zoologia; naturalistas viajantes; Brasil. 
Francisco Inácio Bastos, Magali Romero Sá

$\mathrm{P}$ aulo Emílio Vanzolini (1923- ) is one of the founders of Brazil's contemporary zoology and the author of a comprehensive collection of papers and books in different areas of zoology and biogeography, with a focus on herpetology (i.e. the study of amphibians and reptiles). In the site of the American Society of Ichthyologists and Herpetologists (http://www.asih.org/), he is listed as one of the few honorary foreign members, with two other Brazilians, the polymath Adolfo Lutz $(1855-1940)^{1}$ and the zoologist Naércio Aquino Menezes (1937- ). In 2008, Vanzolini received an award from the Guggenheim Foundation for his lifelong contributions to the progress of science and culture. ${ }^{2}$

\section{A critical appraisal of Vanzolini's contributions}

Other scientists worldwide shared the passion for science with works in the fields of literature, philosophy and arts, such as Jacques Monod (1910-1976), a Nobel laureate in molecular biology who was an accomplished musician and philosopher of science. But to the best of our knowledge, no one became as famous in the field of music as Paulo Vanzolini, who is best known by Brazilians from different generations as the composer of popular songs. Browsing the internet with the help of any searching engine one realizes the composer, poet and originator of popular expressions ('dar a volta por cima', an expression coined by Vanzolini, was included in the main dictionaries of Brazilian Portuguese with the explicit mention of his name as the originator of this expression) eclipsed the herpetologist. The work of Vanzolini as a composer has been analyzed by different musical experts (e.g. Ricardo Cravo Albim in his Dicionário Cravo Albim da música popular brasileira, available at http://www.dicionariompb.com.br/apresentacao.asp) and will not be discussed here.

Vanzolini's contributions as a zoologist have been summarized by standard textbooks, such as the comprehensive volume edited by Adler et al. (2007). One of his most original, but, notwithstanding, controversial contributions was on speciation (more specifically on peripatric speciation). The 'refugia theory' (or 'Pleistocene refuge hypothesis', i.e. a biogeographical hypothesis attributing the speciation of lizards and birds in the Pleistocene due to interspersed hostile environments, later extended to other biological taxa, contexts and periods) has been recognized by most researchers as originally proposed by a complex (and sometimes tense) network of scientists: the German zoologist Jürgen Haffer (1969), the Brazilian biogeographer Aziz Ab'Saber, and Paulo Vanzolini (in collaboration with the American herpetologist Ernest E. Williams, 1970). As usually happens regarding the reconstitution of events taking place in remote times based on scant evidence, the refugia theory has been criticized by some experts (Endler, 1982) and supported by others (Mayr, O’Hara, 1986; Mayr, 1988; Coyne, Orr, 2004). It has been also explored with the help of mathematical modeling (Amorim, 1991).

Vanzolini was a policymaker and contributed decisively to the establishment of Fundação de Amparo a Pesquisa do Estado de São Paulo (Fapesp; Foundation for the Advance of Science of the State of São Paulo) and the substantial improvement and modernization of the Museu de Zoologia da Universidade de São Paulo, an institution he directed for many years (SBPC, 1998). 
Besides a brief biography and interview in the book Cientistas do Brasil, edited by Sociedade Brasileira para o Progresso da Ciência (SBPC, 1998; the Brazilian equivalent of the North-American AAAS - The American Association for the Advancement of Science) and the vast material about Vanzolini's musical works, no comprehensive account of his different scientific activities can be found in books or papers published in Brazil. The then young Vanzolini appears in a brief note in the classical book on the history of Brazilian science edited by Fernando Azevedo in 1955 (Azevedo, 1994) as a promising scientist, who had just returned from his graduate studies at Harvard. Motoyama's (2004) history of science in Brazil briefly highlights his role as one of the key persons involved in the creation of Fapesp. Far from comprehensive, but more informative, Vanzolini's page at the Ministry of Science virtual 'hall of fame' (Notáveis de Ciência e Tecnologia do Brasil) comprises biographical data and some material to be downloaded, including pictures, a short biography, and MP3 files (http://www.canalciencia.ibict.br/menu/listaNotaveis.html).

One could hypothesize such paucity of information on Vanzolini as a scientist and policymaker is a consequence of his multiple activities in too many different fields or a consequence of the fame of the musician which obfuscates the scientist in a country where music is immensely popular and the history of science is cultivated by a restricted number of scholars and readers. However, from our own point of view, such explanations seem to be true, but nevertheless, partial. Vanzolini's contributions do not easily fit the current trends of biological science in Brazil and worldwide, and cannot be viewed either as the work of a contemporary classic ${ }^{3}$, such as the breakthrough contributions of his former teacher at Harvard, the zoologist (ornithologist), evolutionary biologist, philosopher and historian of science, Ernst Mayr (1904-2005; Haffer, 2008).

Both Mayr and his former graduate student Paulo Vanzolini, 19 years younger, can be viewed as 'modern naturalists' in the broad sense of the expression, as defined by Eldredge (1995), i.e. biologists who combine the traditions of classic naturalists with the fundamental insights of the modern evolutionary synthesis.

Vanzolini's contributions to herpetology are very relevant, but do not constitute landmark works such as the classic books and papers by Mayr (see, for instance, the book which is considered the best contemporary work on ornithology from the perspective of systematics, ecology and biogeography - Mayr, Diamond, 2001). In the same sense, Mayr's contributions to the philosophy (1988) and history of biology (1982) constitute indisputable classics of twentieth century biology. Mayr's points of view have been criticized (as discussed below), but his decisive contributions to the history of biological concepts cannot be denied. Writing in Portuguese and exclusively addressing the history of Brazilian science, Vanzolini's contributions to the history of biology are virtually unknown by international scholars.

Both Mayr and Vanzolini did not explore the cutting edge of contemporary biology and produced most of their biological works in the intersection of classic systematics, biogeography and evolutionary biology (Mayr was one of the leading 'architects' of the modern evolutionary synthesis). The contemporary revolutions that deeply affected modern systematics, from the contrasting perspectives of phenetics and cladistics found in Mayr a combative debater (as thoroughly discussed by Hull, 1988) and in Vanzolini a timid arguer. 
Although being the author of a book on basic statistics applied to zoology (1993), Vanzolini did not incorporate bioinformatics or advanced statistics into his later works, developments which were ignored as well by Mayr in his long and prolific career (Mayr published his 25th book when he was hundred years old; see Mayr, 2004). The contemporary integration of molecular biology, embryology and natural sciences, known as Evo Devo (or Evolutionary Developmental Biology) gained momentum in a too recent period to be incorporated by the aging Mayr and Vanzolini. As a very dynamic facet of contemporary biology, Evo Devo deeply changed biological paradigms toward directions unexpected in the time Mayr and Vanzolini wrote their major works (Carroll, 2005).

The present paper addresses the main neglected facet of Vanzolini's works: his contributions to the history of science in Brazil, as recently summarized in a reprint of some of his papers on the origins of zoology in Brazil. The main focus of such collection of works is the seminal contribution of the traveler naturalists who studied Brazil's geography and geology, fauna and flora.

Relatively little has been published overseas about the origins of science in Brazil and the papers and books published in Portuguese have been virtually ignored by international readers. One exception is the recent publication in French of a comprehensive analysis of the role of traveler naturalists in the context of Brazil's colonial science by Kury (2001a).

The contributions of the traveler naturalists took place in a large period of time, beginning when Brazil was a colonial possession of Portugal to the early years of Brazil's Republican life, i.e. from 1638, when Georg Marcgrave (1610-1648) visited Brazil under the patronage of the Dutch prince John Maurice of Nassau (1604-1679) to the Austrian expedition coordinated by Franz Steindachner (1834-1919), in the early years of the twentieth century (1903), which originated publications up to the 1920s. As discussed by Oliveira Pinto (1994), such expeditions coordinated by European Naturalists paved the way for the endogenous growth of Brazilian zoology (and Brazilian and South American science, in a broad sense) in the first years of the twentieth century, first as a poorly integrated activity, basically dependent on its close links with European science (and later with North-American science). Over the years, such efforts evolved toward a concerted set of contributions of Brazilian and international scientists to the Natural Sciences.

Classical historiography has viewed the development of science in Brazil as entirely dependent on the input of foreign scientists, as repeatedly mentioned in Fernando Azevedo's classical book (1994) and even by books published in the late 1970s, such as the comprehensive history of science in Brazil written by Schwartzman (1979). Such historians of science basically understand Brazilian science in this period as a mere reflect of scientific developments taking place in Europe (and, later on, to some extent, of science carried out in the United States, e.g. the works of the Swiss American naturalist Agassiz, as discussed later). However, since the late 1980s such view has been re-evaluated by scholars working both in the broad field of cultural studies, such as the American Brazilianist Richard Morse (1988), and by different historians of science, such as Lopes (1997), Figueirôa (1997) and, more recently, by Freitas (2002), Varela (2009), and the contributors of the anthology organized by Kury (2009) on the activities of the Imperial National Commission (18591961). Such different authors highlight the activities of the Brazilian intellectual elite 
educated at the University of Coimbra, Portugal, in the context of Illuminist science and culture, and describe their scientific activities in the Province of São Paulo carried out as early as 1796 (Varela, 2009). They emphasize the mutually enriching dialogue between the American zoologist Charles Frederick Hartt and his Brazilian colleagues and the key role of Brazilian institutions, such as the National Museum (Freitas, 2002).

The science of traveler naturalists has been explored by different Brazilian scholars, who dedicated a special issue of the journal História, Ciências, Saúde - Manguinhos (v.8, supl., 2001), among other classical (such as the monographs on botany, zoology - as the abovementioned chapter by Oliveira Pinto -, and sociology and anthropology in the collection of essays edited by Fernando de Azevedo, 1994) and recent works (e.g. Grupioni, 1998; Kury, 2001b; Motoyama, 2004).

The present paper discusses Vanzolini's contributions to the history of biology in Brazil, as summarized in his collection of papers Episódios da zoologia brasilica (2004), addressing the originality and validity of his contributions in the context of related analyses by fellow scientists, historians and geographers.

\section{‘Historical' and 'scientific' historians}

Following the typology advanced by Haffer (2008) - a biologist (mentioned before as one of the originators of the 'refugia theory') who became himself Ernst Mayr's biographer (Haffer, 2008) -, after the consolidation of history of science as a discipline in the second half of the twentieth century, two kind of historians of science emerged: 'historical' and 'scientific' historians. The former ones are historians with a professional background in history, other social sciences and/or the humanities. The latter are scientists, such as Haffer himself, Mayr, and Vanzolini, trained in different fields of natural sciences, who decided in some point of their careers to write historical and/or philosophical essays on science, besides the empirical and theoretical work they carried out within their respective disciplines.

The two perspectives should be viewed as complementary and mutually reinforcing, given the complexity of both natural sciences and humanities and the pressing need to implement concerted efforts to capture the most subtle aspects of the history and philosophy of science. But such mutually enriching perspective has been unfortunately not the rule but rather the exception. For instance, Richards (2003), reviewing the treatise written by Mayr on The growth of biological thought (title of his book, originally published in 1982), criticized what he considered Mayr's unfair evaluation of the philosopher and disseminator of evolutionary biology Herbert Spencer (p.21): "This attitude, needless to say, poorly comported with that of the younger, professionally trained historians whose interests became trapped in the tangle of evolution, politics, and social relationships".

The divide between 'historical' and 'scientific' seems to prevail as well in the relationship between Vanzolini's contributions and those by the Brazilian 'historical' historians. Vanzolini's insights about the contributions of the traveler naturalists to Brazilian science have been seldom cited by historians, probably as a consequence of his focus on the development of zoology over time (instead of the broader historical perspective taken by contemporary scholars) and the limited access to his historical papers up to 2004 (when 
his previously scattered articles, most of them published in journals only available in reference libraries, were collected in a single volume). In the abovementioned special issue of História, Ciências, Saúde - Manguinhos on the traveler naturalists, he was mentioned in an interview with the German zoologist Ernst J. Fittkau (2001), who highlighted Vanzolini's (1981) introduction for the new edition of the classic work by Spix and Wagler, as well as by the Brazilian historian Ronald Raminelli (2001). Recently, Raminelli resumed his studies on the traveler naturalists in a comprehensive historical analysis of the role of such naturalists in the context of the relationships between colonial Brazil and Portugal, again recurring to Vanzolini as a reference on their scientific contributions (Raminelli, 2008).

But the absence of a mutually enriching dialogue is far from being an exclusive characteristic of the divide between 'historical' and 'scientific' historians. It can be also discerned in the dissent and conflict between experts from different nationalities and cultures. Vanzolini himself mentions his critical (too critical, from our own perspective) views about the scientific achievements of the Langsdorff's expedition were received with open hostility by his Russian colleagues (on the verge of physical aggression, as described in Vanzolini, 2004, p.58).

\section{The first traveler naturalists}

In the introduction of his paper from 1996 (reprinted as the first chapter of his book published in 2004), Vanzolini lists the criteria used by him in his historical accounts. One can regret the absence of scientists he calls 'residents', such as the Danish paleontologist and zoologist Peter Wilhelm Lund (1801-1880), whose contributions Vanzolini considers unique and quite distinct from those amassed by the traveler naturalists in the context of the classic expeditions. Due to other exclusion criteria, the renowned British evolutionists Henry Walter Bates (1825-1892) and Alfred Russell Wallace (1823-1913) and his expeditions through the Amazon rain forest were also not discussed by him. Such exclusion was justified by him due to the fact both Bates and Wallace worked basically on entomology (whereas Vanzolini focus his historical reviews on vertebrate zoology), besides their main focus on evolutionary biology instead of zoology (being Wallace the co-founder of the Evolutionary Theory, in parallel with Charles Darwin).

Another omission should be added to the ones mentioned by Vanzolini himself: those of the German zoologist (mainly concerned, but not restricted to, invertebrate zoology and one who could be called 'a resident' naturalist, like Lund) and evolutionary biologist Fritz Müller (Johann Friedrich Theodor Müller, 1821-1897), who published fundamental papers on southern Brazilian zoology and evolutionary biology and was one of Darwin's most active correspondents (Papavero, 2003).

Vanzolini opens his text with a brief mention to the scientists he calls the 'precursors', among them the German scientist Georg Marcgrave (1610-1648), whom, together with the Dutch Willem Piso (1611-1678), is considered the first scientist to work in Brazil and the first one to publish a book on the Brazilian fauna and flora (Historia Naturalis Brasiliae, published in 1648), besides a pioneer work on the complex inter-relationships between the tropical environment and different medical conditions (a section basically written by Piso 
for this encyclopedic collaborative work) (available at http://biblio.etnolinguistica.org/ marcgrave-1648-historia). The second precursor mentioned by Vanzolini is the Brazilian naturalist Alexandre Rodrigues Ferreira (Goeldi, 1982), who shall be mentioned again later.

But none of the works by the so-called precursors belong to what Vanzolini considers as 'post-Linean' (after the Swedish naturalist Carl Linnaeus, 1707-1768) zoology, i.e. a zoology developed in the frame of the classification system established by Linnaeus (in his groundbreaking work Systema Naturae, with successive revised editions, until the last one published during his life, the tenth edition, from 1758), in parallel with the emergent proto-ecological approach, comprising the integrated analysis of local faunas and the first steps toward a comprehensive study of biogeography.

In this sense, due to both the abovementioned aspects intrinsic to science, as well as due to the broad historical and political changes determined by the arrival of the Royal Portuguese family in Brazil, in 1810, and the subsequent opening of the country to foreign researchers (translated into the intensification of the exchange of ideas with scientists from different parts of the world), the works of Marcgrave and Rodrigues Ferreira should be viewed as proto-zoological in a modern sense. According to Vanzolini, the scientific commission, brought to Brazil by the archduchess Maria Leopoldina of Austria, which arrived to Brazil in 1817, the year she married the crown prince Pedro I, represents the actual beginning of zoological research in Brazil.

\section{The precursors}

The contribution of the first proto-zoologist, Marcgrave (originally an astronomer), is, accordingly to Vanzolini, basically secondary to the inclusion of new species, depicted in the paintings and engravings (one should observe that in that period the collection and conservation of zoological specimens was still tentative) from his Historia Naturalis Brasiliae (with Piso) into Linaeus' Systema Naturae, and its posterior analysis by the German zoologists Lichtenstein (between 1818-1826) and Schneider, in 1938.

Marcgrave's contributions to zoology have been re-evaluated by the new generation of Brazilian zoologists as fundamental in terms of the progress of ornithology, with the identification of specimens of 52 of the 67 families of the class Aves, identified so far in Northeastern Brazil, a landmark work that took place before the progressive degradation of the local ecosystems gained momentum, affecting in a deep sense the pristine ecosystems (Teixeira, 1992).

Vanzolini describes in some extent the works of Alexandre Rodrigues Ferreira, the single naturalist of that period who was born in Brazil. Rodrigues Ferreira amassed over the years of his 'philosophical' journey a relatively small collection of zoological specimens (especially due to the lack of infrastructure and the deficiencies of the conservation methods in that period), but wrote widely about the fauna, flora, the habits of the different indigenous communities, as well as other aspects of Brazilian Center-West and Amazon, from a broad biomedical (Porto, 2008), social, and economic perspective (Goeldi, 1982). Unfortunately, even such small collection sent to Portugal, housed in the modest Museum of Ajuda, was 
pillaged by the so-called 'mission scientifique en Espagne et en Portugal' (as ironically mentioned by Vanzolini, quoting the Larousse Encyclopedia), coordinated by the French botanist and zoologist Étienne Geoffroy Saint-Hilaire, who arrived in Portugal after the invasion of the country by Napoleon's army. Due to this episode, a substantial part of Ferreira's zoological work was actually published as original findings from Saint-Hilaire (Vanzolini, 2004).

Contemporary historiography sees the Museum of Ajuda as a modest institution in comparison to the huge and well-equipped French and British museums, but, anyway, a relevant institution in the context of the then emerging Portuguese and colonial science (Kury, 2001b, Varela, 2009). The historians corroborate with Vanzolini's critical view about Saint-Hilaire misappropriation of Ferreira's work. However, the latter fact is viewed without the sarcasm characteristic of Vanzolini's style. Notwithstanding, the words of Saint-Hilaire himself about his use of material from fellow scientists without the deserved credit, are nothing but the expression of overt imperialism. In the words of Kury (2001b, p.32, citing the letter from Saint-Hilaire to the British naturalist Joseph Banks: "With the help provided by the French invaders, who would identify and classify the specimens, the Portuguese would get a 'scientific endeavor', instead of the material they have had so far - weed" (emphasis added).

However, some major contributions of Rodrigues Ferreira to zoology survived such unfortunate events, such as descriptive statistics on the Amazon turtle Yurara-reté (Podocnemis expansa), some of the illustrations of his main work (Viagem filosófica), and his monographic work on the mammals from the rivers Amazonas, Negro and Madeira. A final remark made by Vanzolini refers to the debate about the labeling of specimens by Rodrigues Ferreira, an essential part of the work of modern zoologists, in the sense it makes it possible to establish links between individual specimens and the ecosystems they inhabit, or, in other words, the link between systematics and biogeography. It seems that Rodrigues Ferreira, despite his focus on systematics, labeled (even in a non-systematic way) the specimens he collected, but such labels were lost, maybe due to sabotage (what would make this Brazilian scientific pioneer a victim of the worst scientific misconducts!), maybe due to neglect and oblivion.

To the best of our knowledge, contemporary historiography does not corroborate the hypothesis of sabotage, but rather attributes the chaotic labeling of the specimens to the precarious conditions of transportation of specimens across the wild territory of colonial Brazil and the Atlantic Ocean. As cited by Raminelli (2008, p.88): "The effort of collecting and properly packing the specimens was not valued as such, interrupting the adequate flow of information en route to Lisbon, due to the neglect respecting the preservation of specimens and reports sent to Lisbon. After his return to the Court [i.e. Lisbon] after almost ten years, Ferreira verified himself the successive batches he had sent over the years were in a deplorable state, with their labels totally messed up".

\section{Spix and von Martius}

As mentioned before, according to Vanzolini, post-Linean zoology in Brazil has as its founding fathers the German naturalists Johann Baptist von Spix (1781-1826) and Carl 
Friedrich Philipp von Martius (1794-1868), who arrived in Brazil with the archduchess Maria Leopoldina of Austria. Spix and von Martius travelled for almost three years across the contrasting Brazilian regions and landscapes, and either due to strategic reasons (the need to know in detail a vast territory the Portuguese nobles and businessmen wanted to colonize) and/or their own broad curiosity and intellectual interests, coordinated - as Alexandre Rodrigues Ferreira did before - a 'philosophical' expedition encompassing many different disciplines. Spix and von Martius explored in much detail the natural and humanmade environment, from different socioeconomic perspectives such as agriculture, commerce and mining.

Exception made to the southern, extra-tropical landscapes (i.e. the morphoclimatic domains later defined as araucárias and pradarias by Ab'Saber, 2006), Spix and von Martius visited the essential parts of the main Brazilian morphogeographic domains (mata atlântica, caatinga, cerrado, and hileia), paving the way for future developments in the field of geography and ecology by contemporary scholars.

Spix, according to Vanzolini, was a kind of borderline scientist, living on the edge of the old (i.e. informed by classic systematics, emphasizing the identification of new species, but still missing the broader ecological picture) and modern zoology. In modern zoology, systematics has been fully integrated into the broader frame of animal behavior, ecology, evolutionary biology, and, later on, molecular biology.

It will be otiose to repeat here Vanzolini's detailed description of Spix's major findings. There is no way to summarize such remarks due to the very fact their richness is intrinsically linked to the details. We would rather highlight some creative insights from Vanzolini, which provide a conceptual benchmark.

One of Vanzolini's insightful remarks refers to the precociousness of the description of monkeys and non-human primates by researchers (i.e. human primates) vis-à-vis the different taxa composing each given fauna. Besides other characteristics, such as the good conservation of such specimens and their relatively big size (again compared to us, the observers, who define the comparative standards), Vanzolini highlights the fact we share with monkeys and non-human primates a sophisticated (although not as sophisticated as most birds) visually-driven perceptual world (as discussed in detail by contemporary biologists such as Carroll, 2006 and Lane, 2009). It is much easier to recognize animals who share with us the same searching and orientation tools, compared to animals living in a perceptual world driven by sounds or chemical signaling.

On the other hand, bats, the other major group of mammals described by Spix, combine visual and a sonar-like (echolocation)-driven perceptual world, are nocturnal, evasive (they can be captured only through the use of nets), extremely mobile, hard to characterize using apparent morphological traits, and hard to conserve, from the perspective of classical taxidermy. All such specificities constitute sufficient reasons for Spix's gaps and mistakes on bats systematics and for the fact bat zoology remains an open field up to our days.

Vanzolini considers that taking in consideration the complexities of birds systematics, Spix's contributions were properly described and illustrated. The same does not apply to Spix's incursions into herpetology, compromised by the posterior mix of Brazilian and European 
specimens (when specimens were integrated into the collections of European museums) and the multiple synonym descriptions (i.e. different scientific names that pertain to the same taxon). The study of different species of fish was basically accomplished by the Swiss-American naturalist Jean Louis Rodolphe Agassiz (1807-1873), after Spix's premature death.

\section{Wied-Neuwied}

Maximilian Alexander Phillip, Prinz zu Wied-Neuwied (1782-1867) was a German prince and naturalist, whom, after the Napoleonic war, organized an expedition to southeastern Brazil in 1815-1817. Vanzolini places him on the modern side of the zoological transition, ahead of Spix, whom he still considers a borderline researcher. Spix worked on the edge of classic systematics and the emerging biogeographic perspective of modern zoology. WiedNeuwied, on the other hand, was always concerned with the big picture, and worked himself in another frontier, the one between natural sciences and ethnography (which became the focus of his later work). Sharing his findings with many of his fellow scientists, his own contributions became somewhat blurred with other scientists' contributions. Besides, he wrote relevant texts on mammalogy and herpetology, and, above all, made an outstanding contribution to ornithology.

According to Vanzolini, Wied-Neuwied moved ornithology one step further, incorporating not only zoogeographical aspects, but also the analysis of behavior, such as birds' songs and their feeding and reproductive habits. In this sense, he may be viewed as a precursor of the full incorporation of behavioral studies into contemporary ornithology and evolutionary biology (as reviewed by Haffer, 2008, respecting Mayr's works), in parallel, but independently, of Darwin's fragmentary insights on animal behavior, as advanced in his Notebook M, drafted in 1838 (Barett et al., 2008).

One interesting aspect about Vanzolini's insights is the use of quantitative methods to analyze Wied-Neuwied's findings (Vanzolini, 2004; p.38-39). Although the use of quantitative methods constituted a standard procedure in essays written in the field of social and natural sciences overseas (see, for instance, the discussion about factor analysis in the historical essay on racial prejudice and the measurement of intelligence written by Gould, 1996, chapter 6), the use of such methods is exceedingly rare in the Brazilian bibliography on the history of science. Using simple statistics, in the spirit of his former pedagogic book on basic statistics applied to zoology (Vanzolini, 1993), Vanzolini demonstrates that Wied-Neuwied described a representative sample of relevant families of birds, with a bias toward larger and conspicuous species, as well as toward those species best known by local hunters. Once again, as happened to the monkeys collected by Spix, one preferentially describes what has a common ground with the observers themselves, either naturalists or hunters.

Vanzolini also praises the accuracy of Wied-Neuwied's descriptions of reptiles and explain that the too broad nature and lack of infrastructure of Wied-Neuwied's expeditions precluded a better analysis of amphibians. 


\section{Johann Natterer and the Austrian mission}

Johann Natterer (1787-1843) travelled throughout Brazil from 1817 to 1835 . He is considered, side by side with Spix, von Martius and Wied-Neuwied, one of the leading traveler naturalists in the fields of mammalogy and ornithology in South America. Natterer could not explore the southernmost parts of Brazil, the Northeast region and some northern parts of the Atlantic forest, then plagued by political instability and riots. Natterer and the Austrian expedition amassed a large collection of specimens sent to Vienna's Museum of Natural History.

Unfortunately, a fire destroyed the vast majority of Natterer's field notebooks, and the scant material surviving the disaster is nowadays too frail to be consulted and is exclusively available through indirect sources (basically organized by the Austrian zoologist and museum curator August von Pelzeln, 1825-1991).

Using the information compiled by von Pelzeln and other historical and contemporary geographic sources, Vanzolini reconstructed Natterer's itineraries after a manual painstaking effort, he used once again in his attempts to reconstruct the itinerary of the Austrian Expedition of 1903 (see a critical appraisal of such efforts in the section on such Expedition).

After a brief historical introduction, the extensive paper (originally published in 1993, comprising 44 pages of texts and maps) dedicated by Vanzolini to Natterer's travels comprises a thorough reconstruction of his itineraries, using both minute verbal descriptions and several different maps. No comprehensive evaluation of Natterer's contributions to zoology is provided in this geography-driven paper. However such contributions were summarized in a subsequent paper by Vanzolini (originally published in 1996, and reprinted as the first chapter of Vanzolini, 2004).

Vanzolini (in agreement with the German Ornithologist Erwin Stresemann,1889-1972) praises the excellent labeling procedures adopted by Natterer, both from the point of view of systematics (including minute descriptions of the biometric properties of each specimen, as well as a description of their most vulnerable components, such as the soft parts putatively jeopardized by the conservation procedures available in that period) and biogeographic information. Natterer was also an accomplished taxidermist. On the other hand, he laments his meager scientific output (two papers). Vanzolini interprets Natterer's modest scientific output as a consequence of his decades-long commitment to field work. After such period, Natterer lived in Europe for seven years (his last travel was concluded in 1835 and he died in 1843). He also lacked familiarity with the developments of zoology of his time, something easily understood respecting a man who lived most of his lived totally isolated from European science, in the Brazilian countryside.

\section{Castelnau}

François Louis de la Porte (1810-1880), comte de Castelnau, a French naturalist who was born in London, coordinated an expedition throughout South America, part of them throughout Brazil, departing from Rio de Janeiro and reaching the Brazil-Bolivia border (1843-1845). From there, he returned to Rio through the Amazon rain forest. Castelnau 
returned to France in 1847, but was then appointed the French consul in Salvador, Bahia, where he wrote his six books describing his travels, including four books on Brazilian fauna and flora, a truly encyclopedic work, profiting from the contribution of specialists from many different areas. This encyclopedic work provides a comprehensive description of life and nature in Brazil and other South American countries.

The team of zoologists led by Castelnau provided useful descriptions about the local fauna of mammals, including a preliminary assessment of South American bats, and reflecting the deep prejudices of that period - an analysis of the skulls of different Indian tribes, carried out by mammalogists!

Castelnau's team of zoologists, botanists and paleontologists explored three key aspects of modern zoology, according to Vanzolini: they advanced a kind of proto-ecology, still tentative, but notwithstanding situated on the side of modern zoology; carried out detailed anatomical studies in the field, performing careful dissections of different animals, as originally proposed by Cuvier's landmark contributions; and preserved and studied the skeletons of different specimens dissected by them. Castelnau's team contributions seem to Vanzolini relevant in terms of the study of birds and mammals, irrelevant in the field of herpetology, and excellent respecting the collection and detailed study of South American fish.

Unlike Vanzolini, contemporary Brazilian historiography is very critical respecting Castelnau's work (Kury, 2009). The re-evaluation of his findings and analyses highlighted many mistakes and gaps, and such caveats have been associated with the very genesis of the Comissão Científica do Império (Imperial Scientific Commission), an expedition funded and coordinated by Brazilians, viewed by one of his stakeholders, the Brazilian naturalist Manuel Ferreira Lagos, as a way to correct the mistakes committed by Castelnau and his team.

\section{Langsdorff}

Grigori Ivanovitch Langsdorff or Georg Heinrich von Langsdorff (1774-1852) was a Prussian noble, diplomat and naturalist who lived most of his life in Russia. He was nominated consul general in Rio de Janeiro, Brazil, in 1813. In 1821, he proposed to the Tsar Alexander I and the Russian Imperial Academy of Sciences (of which he was a prominent member) to fund a large expedition throughout Brazil. The expedition was actually launched in 1826 .

Langsdorff's diaries were carefully edited in Brazil, with abundant notes, comments, pictures and drawings, under the auspices of the Fundação Oswaldo Cruz and the Langsdorff International Studies Association (Silva, 1997), an association that has been active in Brazil since the 1990s. Langsdorff is a kind of national icon for most Brazilian and Russian historians. They would probably become as surprised as the Russian experts who tried to beat Vanzolini in a seminar (as mentioned before), after reading Vanzolini's critical remarks about Langsdorff's legacy, a legacy he considers close to null from the perspective of zoology.

Vanzolini acknowledges the high quality of the illustrations produced by three talented artists hired by the Langsdorff's expedition (Johann Moritz Rugendas, Aimé-Adrien Taunay 
and Hercules Florence), as well as the major contributions of the expedition in terms of a thorough documentation of Brazil's social life and ethnography. Notwithstanding, his analysis of Langsdorff's achievements is very critical - according to him, it represents an unfortunate example to be averted by other biologists. As discussed by Vanzolini, biological collections, irrespectively of their intrinsic value (in the case of Langsdorff, considered by Vanzolini of modest value), must be thoroughly analyzed with the tools and concepts of each historical period, what Langsdorff's team did not perform. Without further analyses, collections are mute, and, over time, become outdated and nothing but a scientific curiosity (no doubt, a harsh evaluation of Langsdorff's expedition!).

Most Brazilian and international scholars do not endorse Vanzolini's critical views, and instead emphasize the relevant findings of Langsdorff's expedition in a broader sense (in the field of natural sciences and ethnography, not restricted to zoology). From Vanzolini's perspective, the main point to be highlighted is the virtual absence of comprehensive zoological analyses based on the specimens collected by the expedition. In this sense the expedition actually failed, with the early departure of its senior zoologists (the French entomologist Édouard Ménétries and the German zoologist Christian Hasse) and due to the bad conservation of the specimens in the Saint Petesburg's Zoological Museum to where they were sent. On the other hand, those who analyze the vast collection of documents and plates produced by the expedition emphasize their high quality and comprehensiveness, despite being produced in the context of Langsdorff's serious illness and the short period the expedition benefited from the input of its zoologists (Barman, 1971).

\section{Agassiz}

The Swiss-American naturalist Jean Louis Rodolphe Agassiz (1807-1873) began his career as a glaciologist, but since his youth published groundbreaking work on fish, first as one of the scholars in charge of Spix and von Martius collection (as mentioned before) and then on fossilized fish, on which he published a comprehensive textbook. In 1865, as a leading biologist working in the United States, he organized an expedition financed by the American benefactor Nataniel Thayer (named after him) and endorsed by the Brazilian Emperor Pedro II.

The Thayer expedition remained in Brazil for 14 months, and made contributions in the field of geology (mainly due to the contribution of Charles Frederick Hartt, then a young researcher hired by Agassiz) and the study of some Amazonian animals, especially fish, studied by Agassiz himself.

Vanzolini does not consider the Thayer expedition a successful one, and he attributed his failures to the immaturity of most of his young fellows, the absence of a proper contextualization of the collections in the frame of local ecology, and last but not least, due to the original sin of Langsdorff, repeated by Agassiz - the absence of in-depth analyses of the material in due time. Vanzolini does not conceal his deception when, as a graduate student at Harvard, he was invited to analyze the Thayer expedition collection and realized it had many gaps and fundamental mistakes in terms of specimen's labeling. 
In a recent book, Marcus Vinícius de Freitas (2002) analyzing the scientific and cultural legacy of the American naturalist Charles Frederick Hartt, one of Agassiz's most talented disciples, recognizes the limitations of the Thayer expedition. But Freitas attributed its many gaps and misguided analyses to the mistaken emphasis of Agassiz on the hypothetical influence of glaciations on Brazil's geological strata, the so-called drift hypothesis, originally formulated to explain the geology of the Alps (a hypothesis he obsessively sought in different regions of Brazil, with the waste of much time and energy). Freitas blames also Agassiz's pre-Darwinian worldview for his failures. Such misguided views drained much of his time and efforts to the frustrated collection of anti-evolutionary empirical evidence. On the other hand, the subsequent expeditions to Brazil coordinated by Hartt himself where very successful, with the collection and analysis of abundant empirical evidence in the fields of geology, zoology, and ethnography. Such empirical evidence helped Hartt to refute the drift hypothesis and to overcome his former mentor's prejudices and misunderstandings respecting the emerging evolutionary theory, as proposed by Darwin, Wallace, their coworkers and disciples.

\section{The Austrian Expedition of 1903}

Vanzolini, in his paper published 1992 on the Austrian Expedition, coordinated by Franz Steindachner, made once again a painstaking attempt to reconstruct the itinerary of the Austrian Expedition through Brazil's northeast, as he did respecting Natterer's travels.

In his effort, Vanzolini uses the original work published by Otmar Reiser on Ornithology (Reiser, 1926, cited in Vanzolini, 2004) as the key source of information on geographic locations. Such information was then triangulated with information available in maps using different geographic scales, as well as geographic dictionaries.

His interesting findings seem to compensate the enormous time and effort the author invested in such endeavor, but one may ask why Vanzolini performed such painstaking work without the help of a computer. Although not fully developed in the early 1990s as in recent years, computerized geographic methods and tools were available since the 1980s. In that period, authors now considered as contemporary classics in the field of historical and medical geography, such as Andrew Cliff, from the University of Cambridge, or Peter Hagget, from the University of Bristol, published seminal books and papers, such as the Atlas of disease distributions: analytical approaches to epidemiological data (Cliff, Hagget, 1988) or their study on the biogeography and epidemiology of disease spread in an island community (Cliff et al., 1981). In this sense, Vanzolini's exhaustive handwork cannot be easily understood by contemporary researchers. We can hypothesize that his option could be secondary to his seniority in that period (the new tools became available and were perfected when he was in his 60s-70s), the almost exclusive use of such methods and tools by scholars with a comprehensive background in quantitative geography, and the deep contrasts between the complexity of the first softwares vis-à-vis their modern user-friendly counterparts, used nowadays by high-school students.

Whatever could be the underlying reasons motivating the author to work on his abundant material without the help from modern methods and tools, his creativity cannot 
be minimized. In some cases ( 25 localities, according to him), he could not obtain the precise geographic latitude and longitude of a given locality and recurred to interpolations using the average traveling speed of such expeditions (usually quite slow), as given by his own empirical experience and historical records, obtaining very reasonable approximations (of plus or minus $5 \mathrm{~km}$ ). Again, despite praising the author for his ingenious interpolation method, there is no doubt he could obtain more precise results with much less effort using the very basic tools of a standard geographic software.

Vanzolini obtained a quite comprehensive reconstruction of the original itinerary, illustrated by distribution (dot) maps, and amassed additional information on localities mentioned by Reiser as sources of biological specimens, beyond the ones made available in the original documents.

\section{Final considerations}

Vanzolini's contributions to the history of natural sciences in Brazil (especially in the fields of zoology and biogeography) should be better integrated with the ample efforts made by contemporary scholars from different backgrounds to reconstruct the birth of Brazilian (and in a broader sense, colonial) science. In that period, Brazilian and colonial science were still tentative and far from being an autonomous and sustainable scientific enterprise. His points of view do not agree many times with established knowledge and have been received with suspicion and even hostility by his critics, such as by most scholars on the merit (or lack of merit) of the expedition coordinated by Langsdorff.

His methods were frequently far from canonical in terms of Brazilian classical historiography, such as in his creative use of quantitative methods to analyze Wied-Neuwied's contributions to ornithology. In other occasions, however, he lost the opportunity to incorporate advanced methods into his researches, such as the computational methods and tools used since the 1970s/1980s to analyze phylogenetic data and geographic information.

His non-orthodoxy coupled with a deep irony, sometimes explicit, sometimes discernible between the lines, plus the mutual suspicion between scholars from the fields of humanities and natural sciences, may have contributed to the modest impact of Vanzolini's writings on the mainstream history of science in Brazil. This paper tries to bring attention to the merit of his contributions, as well as highlighting his limitations, aiming to contribute to a better understanding of the birth of natural sciences in colonial South America.

The answer to the question formulated by Labinger and Collins (2001) about the existence in the contemporary world of 'One Culture' (integrating the natural sciences, the social sciences and the humanities) seems to be, unfortunately, negative but all efforts should be made to bridge the gap between different perspectives and toward a more integrated understanding of the history of science.

\section{NOTES}

${ }^{1}$ Lutz was a biomedical researcher with landmark publications in fields as diverse as the pathophysiology
and clinical management of malaria, leprosy and yellow fever, a leading authority in public health and
tropical medicine, and, last but not least, an accomplished zoologist. His works - scattered through a 
myriad of journals - have been collected, translated (from the original German, French and English publications) and published by Editora Fiocruz in a comprehensive series of boxes with many different volumes each; available at http://www.fiocruz.br/editora/cgi/cgilua.exe/sys/start.htm.

${ }^{2}$ In the very moment this text is being published Vanzolini has just received the Conrad Wessel award of 2011 for 'Culture' (available at http://agencia.fapesp.br/14859).

${ }^{3}$ Very few contemporary Brazilian scientists are viewed as such, a major exception being the physicist Cesar Lattes (available at http://en.wikipedia.org/wiki/Cesar_Lattes).

${ }^{4}$ In this and other citations of texts from non-English languages, a free translation has been provided. "Com a 'ajuda' dos invasores franceses, que identificariam e classificariam os espécimes, os portugueses passariam a ter uma 'propriedade científica', quando até então eles possuíam apenas 'ervas'" (emphasis added).

5 "O esforço de coletar e embalar as espécies não era, portanto, devidamente valorizado, interrompendo o fluxo de informações em direção a Lisboa, devido ao descuido no armazenamento das espécies e memórias remetidas. Ao retornar à Corte, depois de quase dez anos, Ferreira teve a surpresa de encontrar as remessas em péssimo estado, com as etiquetas de identificação embaralhadas."

\section{REFERENCES}

AB'SABER, Aziz N.

Ecossistemas do Brasil. São Paulo: Metalivros. 2006.

ADLER, K., APPLEGARTH, J.S., ALTIG, R. (Ed.). Contributions to the history of herpetology. Salt Lake City: Society for the Study of Amphibians and Reptiles. v.2. 2007.

AMORIM, Dalton de Souza.

Refuge model simulations: testing the theory. Revista Brasileira de Entomologia, Curitiba, v.35, p.803-812. 1991.

AZEVEDO, Fernando (Ed.).

As ciências no Brasil. Rio de Janeiro: Editora da UFRJ. 1994.

BARMAN, Roderick J.

The forgotten journey: Georg Heinrich Langsdorff and the Russian Imperial Scientific Expedition to Brazil, 1821-1829. Terrae Incognitae, s.l., v.3, p.67-96. 1971.

BARRETT, Paul H. et al. (Ed.). Charles Darwin's notebooks. Cambridge: Natural History Museum; Cambridge University Press. 2008.

CARROLL, Sean B.

The making of the fittest: DNA and the ultimate forensic record of evolution. New York: W.W. Norton. 2006.

CARROLL, Sean B.

Endless forms most beautiful: the new science of Evo Devo. New York: W.W. Norton. 2005.

CLIFF, Andrew D., HAGGET, Peter. Atlas of disease distributions: analytical approaches to epidemiological data. Oxford: Blackwell. 1988.
CLIFF, Andrew D. et al.

Spatial diffusion: an historical geography of epidemics in an island community. Cambridge: Cambridge University Press. 1981.

COYNE, Jerry A., ORR, H. Allen. Speciation. Sunderland: Sinauer. 2004.

ELDREDGE, Niles.

Reinventing Darwin: the great debate at the high table of evolutionary theory. New York: John Wiley. 1995.

ENDLER, John A.

Pleistocene forest refuges: fact or fancy? In: Prance, Ghillean T. (Ed.). Biological diversification in the tropics. New York: Columbia University Press. p.641-657. 1982.

FIGUEIRÔA, Sílvia.

As ciências geológicas no Brasil. São Paulo: Hucitec. 1997.

FITTKAU, Ernst Josef.

Johann Baptist Ritter von Spix: primeiro zoólogo de Munique e pesquisador no Brasil. História, Ciência, Saúde - Manguinhos, Rio de Janeiro, v.8, supl., p.1109-1135. 2001.

FREITAS, Marcus Vinícius de.

Charles Frederick Hartt: um naturalista no império de Pedro II. Belo Horizonte: EdUFMG. 2002.

GOELDI, Emil August.

Alexandre Rodrigues Ferreira. Brasília: EdUnb; CNPq. 1982.

GOULD, Stephen Jay.

The mismeasure of man. New York: W.W. Norton. 1996.

GRUPIONI, Luís Donisete Benzi. Coleções e expedições vigiadas: os etnólogos no 
Conselho de Fiscalização das Expedições Artísticas e Científicas no Brasil. São Paulo: Hucitec; Anpocs. 1998.

HAFFER, Jürgen.

Ornithology, evolution, and philosophy: the life and science of Ernst Mayr, 1904-2005. New York: Springer. 2008.

HAFFER, Jürgen.

Speciation in Amazonian forest birds. Science, New York, v.165, n.3889, p.131-137. 1969.

HULL, David L.

Science as a process: an evolutionary account of the social and conceptual development of science. Chicago: The University of Chicago Press. 1988.

KURY, Lorelai B. (Ed.).

Comissão Científica do Império, 1859-1861. Rio de Janeiro: Andrea Jakobsson Estúdio. 2009.

KURY, Lorelai B.

A Comissão Científica de Exploração (1859-

1861): a ciência imperial e a musa cabocla. In: Heizer, Alda; Videira, Antonio Augusto Passos (Ed.). Ciência, civilização e império nos trópicos. Rio de Janeiro: Access. p.29-54. 2001a.

KURY, Lorelai B.

Histoire naturelle et voyages scientifiques (17801830). Paris: L'Harmattan. 2001b.

LABINGER, Jay A.; COLLINS, Harry (Ed.). The one culture? A conversation about science. Chicago: The University of Chicago Press. 2001.

LANE, Nick.

Life ascending: the ten great inventions of evolution. New York: W.W. Norton. 2009.

LOPES, Maria Margaret.

O Brasil descobre a pesquisa científica: os museus e as ciências naturais no século XIX. São Paulo: Hucitec. 1997.

MAYR, Ernst.

What makes biology unique? Considerations on the autonomy of a scientific discipline. New York: Cambridge University Press. 2004.

MAYR, Ernst.

Toward a new philosophy of biology. Cambridge: Harvard University Press. 1988.

MAYR, Ernst.

The growth of biological thought: diversity, evolution, and inheritance. Cambridge: Belknap Press. 1982.

MAYR, Ernst; DIAMOND, Jared. The birds of Northern Melanesia: speciation, ecology and biogeography. Oxford: Oxford University Press. 2001.
MAYR, Ernst; O'HARA, Robert J.

The biogeographic evidence supporting the Pleistocene forest refuge hypothesis. Evolution, Lancaster, v.40, p.55-67. 1986.

MORSE, Richard M.

O espelho de Próspero: cultura e ideias nas Américas. São Paulo: Companhia das Letras. 1988.

MOTOYAMA, Shozo.

Período colonial: o Cruzeiro do Sul na terra do pau-brasil. In: Motoyama, Shozo (Ed.). Prelúdio para uma história: ciência e tecnologia no Brasil. São Paulo: EdUSP. p.59-134. 2004.

OLIVEIRA PINTO, Olivério Mário de. A zoologia no Brasil. In: Azevedo, Fernando (Ed.). As ciências no Brasil. Rio de Janeiro: EdUFRJ. p.109-174. 1.ed., 1955. 1994.

PAPAVERO, Nelson.

Fritz Müller e a comprovação da teoria de Darwin. In: Domingues, Heloísa Maria Bertol; Sá, Magali Romero; Glick, Thomas. (Ed.). A recepção do darwinismo no Brasil. Rio de Janeiro: Editora Fiocruz. p.29-44. 2003.

PORTO, Angela (Ed.). Enfermidades endêmicas da capitania de Mato Grosso: a memória de Alexandre Rodrigues Ferreira. Rio de Janeiro: Editora Fiocruz; Faperj. 2008.

RAMINELLI, Ronald.

Viagens ultramarinas: monarcas, vassalos e governo à distância. São Paulo: Alameda. 2008.

RAMINELLI, Ronald.

Do conhecimento físico e moral dos povos: iconografia e taxionomia na Viagem Filosófica de Alexandre Rodrigues Ferreira. História, Ciência, Saúde - Manguinhos, Rio de Janeiro, v.8, supl., p.969-992. 2001.

RICHARDS, Robert J.

Biology. In: Cahan, D. (Ed.). From natural philosophy to the sciences. Chicago: The University of Chicago Press. p.16-48. 2003.

SBPC.

Sociedade Brasileira Para o Progresso da Ciência. Cientistas do Brasil: depoimentos. São Paulo: SBPC. p.663-680. 1998.

SCHWARTZMAN, Simon.

Formação da comunidade científica nacional. São Paulo: Editora Nacional; Rio de Janeiro: Finep. 1979.

SILVA, Danuzio Gil Bernardino da (Ed.). Os diários de Langsdorff. Rio de Janeiro: Fiocruz. v.1. 1997.

TEIXEIRA, Dante Martins.

As fontes do paraíso: um ensaio sobre a 
ornitologia no Brasil holandês (1624-1654). Revista Nordestina de Biologia, João Pessoa, v.7, p.1-232. 1992.

VANZOLINI, Paulo Emílio.

Episódios da zoologia brasílica. São Paulo: Hucitec. 2004.

VANZOLINI, Paulo Emílio.

Métodos estatísticos elementares em sistemática zoológica. São Paulo: Hucitec. 1993.

VANZOLINI, Paulo Emílio.

Introduction. In: Spix, Johann Baptist von; Wagler, Johann Georg. Herpetology of Brazil.

Kansas: Society for the Study of Amphibians and Reptiles. Facsimile reprints in Herpetology Series. 1981.
VANZOLINI, Paulo Emílio; WILLIAMS, Ernest. South American anoles: the geographic differentiation and evolution of the Anolis chrysolepis species group (Sauria, Iguanidae). Arquivos de Zoologia de São Paulo, São Paulo, v.19, n.1-2, p.1-176. 1970.

VARELA, Alex Gonçalves.

Atividades científicas na "bela e bárbara" capitania de São Paulo (1796-1823). São Paulo: Annablume. 2009.

WILSON, R.C.L.; DRURY, Stephen A.; CHAPMAN, J.L.

The great Ice Age: climate change and life. New York: Routledge. 1999.

\section{$\rightarrow \rightarrow \rightarrow<<<$}

